\title{
FAKTOR-FAKTOR YANG MEMPENGARUHI KETERANDALAN DAN KETEPATWAKTUAN PELAPORAN KEUANGAN PEMERINTAH DAERAH
}

\author{
Irene Avi Megasiwi ${ }^{1}$, Priyo Hari Adi ${ }^{2}$ \\ ${ }^{1)}$ Fakultas Ekonomika dan Bisnis \\ Universitas Kristen Satya Wacana Salatiga \\ ${ }^{2)}$ Fakultas Ekonomika dan Bisnis \\ Universitas Kristen Satya Wacana Salatiga \\ Email:priyo.adi@uksw
}

\begin{abstract}
The purposes of the research are to examine: the influences of quality human recources the use of information technology amd internal controling system to reliability and timeliness. The respondent of this research is all of accountancy/financial employees of OPD in Pemerintahan Kota Salatiga. The method to cillecting data is using questioner. The method to analyze the datas are using regression. The result of this research indicates the the use of information technology, and internal controling system significantly influence both the reliability and timeliness. While the quality human resource positive significantly influences the reliability but not the timeliness.
\end{abstract}

Keywords; quality human resource, the use of information technology, internal control system, reliability, and timeliness

Abstrak: Penelitian ini bertujuan untuk menguji: pengaruh kualitas sumber daya manusia terhadap keterandalan dan ketepatwaktuan, pengaruh pemanfaatan teknologi informasi terhadap keterandalan dan ketepatwaktuan, pengaruh sistem pengendalian internal terhadap keterandalan dan ketepatwaktuan. Responden yang digunakan adalah seluruh pegawai OPD bagian akuntansi/keuangan di Pemerintah Kota Salatiga. Metode pengumpulan data dengan menggunakan kuesioner. Metode pengolahan data dengan menggunakan regresi linear berganda. Hasil penelitian menunjukkan bahwa pemanfaatan teknologi informasi dan sistem pengendalian internal berpengaruh positif baik terhadap keterandalan maupun ketepatwaktuan. Sementara itu, kualitas SDM hanya mempunyai pengaruh positif terhadap ketepatwaktuan.

Kata kunci: kualitas SDM, pemanfaatan teknologi informasi, keterandalan, dan ketepatwaktuan

\section{Pendahuluan}

Seiring dengan reformasi manajemen pemerintahan, tuntutan pada good governance goverment menjadi semakin tinggi. Pemerintah dituntut untuk semakin akuntabel dalam mempertanggungjawabkan, menyajikan, melaporkan, dan mengungkapkan segala sesuatu kepada para pemberi amanah yang berhak dan memiliki kewenangan untuk menerima partanggungjawaban tersebut (Renyowijoyo 2010). Untuk menegaskan akuntabilitas terhadap pelaporan keuangan pemerintah maka pemerintah wajib untuk mempublikasikan laporan keuangan, karena laporan keuangan yang diterbitkan tersebut akan dijadikan acuan oleh para pemangku kepentingan dalam pengambilan keputusan. Dari hal tersebut dapat disimpulkan bahwa informasi yang ada di dalam laporan keuangan pemerintah harus bermanfaat dan sejalan dengan kebutuhan yang memakai laporan keuangan tersebut (Arfianti 2011).

Untuk memenuhi kriteria kebermanfaatan dari sebuah laporan keuangan, di dalam Peraturan Pemerintah Nomor 71 Tahun 2010 tentang Standar Akuntansi Pemerintahan dinyatakan bahwa karakteristik kualitatif laporan keuangan yaitu relevan, andal, dapat 
dibandingkan, dan dapat dipahami. Keempat komponen tersebut dimaksudkan supaya laporan keuangan nantinya dapat memberikan nilai atau manfaat bagi para penggunanya. Sari dan Witono (2014) menjelaskan bahwa keterandalan dan ketepatwaktuan harus menjadi perhatian supaya laporan keuangan dapat digunakan dan memenuhi kebermanfaatan berdasarkan PP Nomor 71 Tahun 2010. Kedua hal tersebut harus terpenuhi. Jika sudah memenuhi kriteria tepat waktu namun tidak dapat diandalkan maka laporan keuangan tidak akan berguna. Begitu pula sebaliknya, jika laporan keuangan andal namun ketika dibutuhkan tidak tersedia maka akan mengganggu dalam proses pengambilan keputusan oleh pihak yang berkepentingan.

Faktor pertama bahwa informasi yang bernilai dapat dicapai dengan salah satu elemen pentingnya yaitu sumber daya manusia (SDM) (Wahyono 2004). Keberlangsungan jalannya suatu organisasi menjadi lebih baik ketika memiliki pekerja (SDM) yang memiliki pendidikan dan ketrampilan di bidang yang mereka tekuni. Adanya sumber daya manusia yang berkompeten akan mempengaruhi bagaimana hasil akhir dari kinerja yang telah dilakukan (Notoadmodjo 2003). Studi mengenai pengaruh kualitas sumber daya manusia pada keterandalan laporan keuangan pernah dilakukan oleh Megayanti, Adiputra dan Sinarwati (2015), Surastiani dan Handayani (2015), Sari dan Witono (2014), Darwanis dan Mahyani (2009), yang memberikan hasil positif.

Faktor kedua yang diperkirakan mempengaruhi nilai informasi laporan keuangan pemerintah daerah berupa keterandalan ialah penggunaan teknologi informasi. Pengaruh kedua variabel tersebut pernah diteliti oleh Megayanti, Adiputra dan Sinarwati (2015), Sari dan Witono (2014), Darwanis dan Mahyani (2009) yang menunjukkan hasil positif. Untuk ketepatwaktuan, kajian tentang penggunaan teknologi informasi dilakukan oleh Sari dan Witono (2014) juga menunjukkan hasil positif yaitu ada pengaruh antara keduanya. Hal ini dikarenakan penggunaan atau pemanfaatan teknologi informasi memiliki peran yang penting seperti dalam urusan transaksi elektronik. Disisi lain pengelolaan teknologi informasi dapat membantu meningkatkan pelayanan pemerintah terhadap masyarakat terutama supaya $e$ government dapat terlaksana dengan cepat (Hamzah 2009). Hal lain yang menjadi dampak baik danya penggunaan teknologi informasi adalah dapat membantu pekerjaan aparatur pemerintahan khususnya dalam menyusun laporan keuangan karena dapat dilakukan dengan lebih mudah, cepat, serta akurat dibandingkan jika harus menyusunnya dengan sistem konvensional.

Adanya kualitas sumber daya manusia dan pemanfaatan teknologi informasi akan dapat terselenggarakan dengan baik jika didukung dengan faktor ketiga yaitu sistem pengendalian internal (SPI) yang baik pula. Sistem pengendalian internal ini merupakan implikasi dari Sistem Pengendalian Internal Pemerintah (SPIP) yang berpatokan pada Peraturan Pemerintah Nomor 60 Tahun 2008 tentang Sistem Pengendalian Intern. Terdapat beberapa penelitian yang telah dilakukan oleh Megayanti, Adiputra dan Sinarwati (2015), Surastiani dan Handayani (2015), Sari dan Witono (2014), Darwanis dan Mahyani (2009) yang mengkaji tentang pengaruh sistem pengendalian internal terhadap keterandalan pelaporan keuangan. Hasilnya menunjukkan hasil yang positif yaitu terdapat pengaruh dari kedua variabel tersebut. Disisi lain Sari dan Witono (2014) juga melakukan penelitian pengaruh SPI terhadap ketepatwaktuan pelaporan keuangan dan memberikan hasil positif.

Penelitian akan dilakukan di Pemerintahan Kota Salatiga dengan alasan bahwa untuk mendapatkan predikat opini audit Wajar Tanpa 
Pengecualian (WTP) Pemerintah Kota Salatiga harus menunggu selama 11 tahun lamanya, dan baru pada tahun anggaran 2016 Pemkot Salatiga yang pada saat itu dipimpin oleh Wali Kota Yulianto dan Haris sebagai Wakil Wali Kota mendapat opini WTP dari Badan Pemeriksa Keuangan (BPK) (Setiawan 2017). Berdasarkan Laporan Hasil Pemeriksaan Laporan Keuangan Pemerintah Daerah (LHP LKPD), Kota Salatiga pada tahun anggaran 2015 mengalami perbaikan yang dibuktikan pada LHP LKPD pada tahun anggaran 2016. Perbaikan ini yang membuat pada akhirnya Pemkot Salatiga mendapatkan opiniaudit WTP dari BPK. Penelitian akan dilakukan pada Organisasi Perangkat Daerah (OPD) dengan alasan bahwa terbentuknya laporan keuangan pemerintah daerah berasal dari laporan keuangan yang telah dibuat oleh OPD. OPD merupakan perangkat daerah yang bertindak sebagai pengguna anggaran dan pengguna barang, oleh sebab itu dalam kegiatannya tersebut OPD wajib membuat surat pertanggungjawaban dalam bentuk laporan keuangan (Permendagri No. 13 Tahun 2006 Pasal $10 \mathrm{k}$ ). Sehingga dengan kata lain laporan keuangan pemeritah daerah merupakan hasil konsolidasi dari laporan-laporan keuangan yang dibuat oleh OPD.

Terdapat dua variabel terikat yaitu keterandalan dan ketepatwaktuan, serta tiga variabel bebas yaitu kualitas sumber daya manusia, pemanfaatan teknologi informasi, dan sistem pengendalian internal. Berdasarkan fenomena yang terjadi penelitian saat ini ingin memberikan bukti apakah terdapat pengaruh antara variabel-variabel bebas tersebut terhadap keterandalan serta ketepatwaktuan dalam penyusunan laporan keuangan di Pemerintah Kota Salatiga. Sebagaimana dipaparkan diawal, dibutuhkan waktu 11 tahun oleh Pemerintah Kota Salatiga untuk mendapatkan opini wajar tanpa pengecualian Hal ini memberikan indikasi adanya persoalan terkait dengan kompentensi sumber daya manusia untuk menghasilkkan laporan keuangan yang tepat waktu dan akurat. Haryanto (2013) menjelaskan bahwa salah satu kendala yang banyak dihadapi oleh pemerintah daerah dalam penyusunan laporan keuangan adalah menyangkut kompetensi dari aparatur penyusun laporan, baik dalam memahami ketentuan standar akuntansi (pemerintahan) yang terbaru maupun dalam menggunakan teknologi informasi Akibatnya, pemerintah daerah bisa saja lebih memfokuskan pada ketepatwaktuan penyampaian laporan, sehingga dimensi keterandalan dapat terabaikan atau sebaliknya. Focus penelitian ini yaitu ingin mencoba melihat apakah masing-masing dari variabel bebas lebih dominan dalam mempengaruhi keterandalan ataukan ketepatwaktuan. Alasannya adalah kualitas sumber daya manusia, pemanfaatan teknologi informasi, dan sistem pengendalian internal harus seimbang dalam fokusnya menciptakan laporan keuangan yang andal sekaligus tepat waktu. Kedua unsur andal dan tepat waktu harus semuanya terpenuhi agar laporan keuangan dapat digunakan bagi pihak yang berkepentingan.

Indikasi bahwa sumber daya manusia gagal dan tidak menguasai logika akuntansi adalah adanya kesalahan di dalam laporan keuangan serta adanya ketidaksesuaian laporan keuangan tersebut dengan standar yang sedang berlaku (Warisno 2009). Standar yang ada dibuat sebagai pedoman dalam sumber daya manusia menyusun sebuah laporan keuangan serta untuk meminimalisasi terjadinya penyimpangan yang tidak diinginkan. Atas adanya tuntutan terhadap penyelesaian laporan keuangan yang sesuai dengan standar serta tidak adanya kesalahan, diperlukan kualitas sumber daya manusia yang ahli dalam bidang akuntansi khususnya. Hal ini dilakukan supaya keterandalan dapat tercapai sehingga informasi terbebas dari bias dan kesalahan yang signifikan. Dengan kalimat lain, keterandalan dapat tercapai dengan dimilikinya sumber daya manusia yang berkompeten di dalam 
organisasi diukur dari pendidikan, keterlatihan, dan pengalaman yang dimilikinya (Susilo 2002).

Penelitian tentang pengaruh kualitas sumber daya manusia terhadap keterandalan pernah dilakukan oleh Megayanti, Adiputra dan Sinarwati (2015). Dalam penelitian tersebut menggunakan populasi seluruh kepala bagian keuangan, staf pencatatan keuangan dan para pemegang kas yang terlibat langsung dalam pembuatan laporan keuangan di 20 OPD Kabupaten Jembrana. Didapatkan 60 orang responden dengan metode purposive sampling dalam penentuan jumlah sampelnya. Hasil penelitian menunjukkan bahwa kualitas sumber daya manusia memiliki pengaruh positif pada keterandalan pelaporan keuangan. Sari dan Witono (2014) melakukan penelitian yang sejenis. Dengan metode convinience sampling penelitian tersebut mengambil sampel 290 orang pada Dinas Pendapatan, Pengelolaan Keuangan dan Aset Daerah (DPPKAD). Hasil penelitian yang menggunakan pengujian regresi linear berganda menunjukkan bahwa kualitas sumber daya manusia memiliki pengaruh positif terhadap keterandalan pelaporan keuangan pemerintah daerah. Darwanis dan Mahyani (2009) menginvestigasi hal yang sama namun berbeda tempat yaitu pada Satuan Kerja Perangkat Aceh (SKPA) di Nanggroe Aceh Darussalam. Penelitian ini menggunakan populasi seluruh kepala SKPA dan menetapkan sampel berjumlah 111 responden yang dilakukan secara sensus yang berarti semua anggota populasi dijadikan sebagai responden di dalam penelitiannya. Didapatkan hasil jika keterandalan pelaporan keuangan dipengaruhi oleh kualitas sumber daya manusia, yang artinya menunjukkan hasil yang positif. Atas kajian yang dipaparkan oleh tiga penelitian diatas menimbulkan indikasi bahwa kualitas sumber daya manusia memang turut andil dalam terciptanya sebuah laporan keuangan yang andal.
Dalam Peraturan Pemerintah Nomor 56 Tahun 2005 yang kemudian diperbaharui dalam Peraturan Pemerintah Nomor 65 Tahun 2010 mengenai Sistem Informasi Keuangan Daerah disebutkan bahwa pemerintah dan pemerintah daerah wajib mengembangkan kemampuan dalam pengelolaan keuangan daerah dan menyalurkan informasi tersebut kepada publik untuk mendukung adanya good governance. Untuk mengurangi adanya bias yang menyesatkan dalam penggunaan laporan keuangan, maka diperlukan ketelitian dan keakuratan dalam pembuatannya sehingga laporan keuangan menjadi terandal. Teknologi informasi dipercaya dapat membantu aparatur pemerintahan dalam melakukan pembuatan laporan keuangan yang lebih sistematis dan minim kesalahan, mengingat bahwa transaksi-transaksi yang terjadi di dalam organisasi pemerintahan merupakan transaksi yang kompleks (Sari dan Witono 2014). Kajian penelitian yang telah dilakukan oleh Megayanti, Adiputra dan Sinarwati (2015) menginvestigasi mengenai apakah pemanfaatan teknologi informasi ikut mempengaruhi terciptanya keterandalan sebuah laporan keuangan. Penelitian yang dilakukan di Kabupaten Jembrana menunjukkan hasil yang positif. Penelitian yang sama dilakukan juga oleh Sari dan Witono (2014) pada DPPKAD yang menunjukkan ada pengaruh positif antara penggunaan teknologi informasi terhadap keterandalan. Investigasi lain yang sejenis telah dilakukan juga oleh Darwanis dan Mahayani (2009). Penelitian mereka menunjukkan hasil yang positif bahwa ada pengaruh antara pemanfaatan teknologi informasi dengan keterandalan pelaporan keuangan. Tiga penelitian sudah pernah dilakukan dan ketiganya menunjukkan hasil yang positif, sehingga diindikasikan bahwa pemanfaatan teknologi informasi turut ambil bagian dalam terciptanya keterandalan pelaporan keuangan.

\begin{tabular}{cccr} 
Sebuah & \multicolumn{2}{c}{ sistem } & pengendalian \\
rancang & untuk tujuan & menjaga \\
ekayaan & dari & para & pemangku
\end{tabular}


kepentingan, meningkatkan kepercayaan mereka terhadap dana yang sudah mereka investasikan, serta untuk memberikan keyakinan akan kualitas dan keandalan dari informasi laporan keuangan yang diterbitkan (Mulyadi 2001). Demikian juga pada organisasi pemerintahan, pengendalian internal diharapkan mampu melaksanakan pengawasan serta pencegahan fraud dan error khususnya dalam proses akuntansi untuk mencapai suatu keterandalan di dalam sebuah laporan keuangan. Berbagai penelitian mengenai hal tersebut telah dilakukan, seperti yang telah dilakukan oleh Darwanis dan Mahyani (2009), Sari dan Witono (2014), Surastiani dan Handayani (2015), Megayanti, Adiputra dan Sinarwati (2015) yang menginvestigasi mengenai apakah sistem pengendalian internal turut berpengaruh pada terciptanya sebuah laporan keuangan yang terandal pada organisasi pemerintah daerah. Sesuai dengan hasil penelitian mereka yang menunjukkan hasil positif, maka diindikasikan bahwa sistem pengendalian internal ikut ambil bagian dalam terciptanya keterandalan sebuah laporan keuangan pada organisasi pemerintahan

Berdasarkan Peraturan Pemerintah Nomor 71 Tahun 2010 tepat waktu merupakan tersedianya suatu informasi pada saat akan dilakukannya pengambilan sebuah keputusan. Laporan keuangan berasal dari berbagai macam transaksi yang dilakukan oleh manusia didalam sebuah organisasi. Dan, manusia pula yang memiliki kecerdasan pemikiran untuk dapat menyusun segala bentuk transaksi tersebut di dalam sebuah laporan keuangan dengan tujuan agar laporan keuangan tersebut dapat memiliki manfaat bagi khalayak yang membutuhkannya. Untuk dapat memenuhi kebermanfaatan dari laporan keuangan tersebut, tepat waktu merupakan hal yang harus diperhatikan bagi penusun laporan keuangan. Laporan keuangan tidak akan berguna lagi jika ketika dibutuhkan dalam sebuah pengambilan keputusan, laporan keuangan tersebut tidak tersedia atau bahkan penyusunannya belum selesai dilakukan. Ketidaktepatwaktuan ini dapat diminimalisasi jika didukung dengan adanya kualitas sumber daya manusia yang memiliki kompetensi di bidangnya (bidang akuntansi) (Winidyaningrum dan Rahmawati 2010). Dengan ungkapan lain, sumber daya manusia yang berkompeten dapat membantu sebuah organisasi dalam mempercepat pembuatan laporan keuangan sehingga penyajiannya tidak akan mengalami sebuah ketidaktepatwaktuan.

Ketepatwaktuan adalah salah satu aspek untuk menjamin laporan keuangan berfungsi sebagai mana mestinya. Ketepatwaktuan dapat dicapai jika para pegawai pemerintahan dapat melakukan penyusunan laporan keuangan secara cepat tanpa menghilangkan nilai keakuratan serta kekonsistenan di dalam laporan keuangan. Untuk mewujudkan ketepatwaktuan tersebut maka peran teknologi informasi diperlukan (Winidyaningrum dan Rahmawati 2010). Hal ini terdukung dengan penelitian yang telah dilakukan oleh Sari dan Witono (2014) dengan hasil penelitian bahwa pemanfaatan teknologi informasi memiliki dampak pada terselesaikannya laporan keuangan pemerintah daerah secara tepatwaktu sehingga laporan keuangan tidak kehilangan nilainya. Penelitian tersebut menunjukkan hasil yang positif, bahwa teknologi informasi memiliki peran dalam terselesaikannya sebuah laporan keuangan secara tepatwaktu.

Pengendalian internal dapat membantu terciptanya ketertiban dalam pelaporan keuangan yaitu terbitnya laporan keuangan secara tepat waktu. Pengendalian internal diadakan supaya asas ketertiban dapat terpenuhi di dalam pelaporan keuangan pemerintah daerah yang merupakan cermin dari ketaatan terhadap peraturan perundang-undangan. Wujud asas ketertiban tersebut ditunjukkan dengan ketepatwaktuan pelaporan keuangan (Mirnayanti 2013). Dengan adanya pengendalian internal 
yang memadai akan mendorong ketepatwaktuan pelaporan keuangan pemerintah daerah. Uraian tersebut sejalan dengan penelitian yang telah dilakukan oleh Sari dan Witono (2014) yang menggunakan pengujian regresi linear berganda dan menggunakan convenience sampling dalam pengambilan sampelnya. Sari dan Witono (2014) menginvestigasi pengaruh sistem pengendalian internal terhadap ketepatwaktuan pelaporan keuangan pemerintah daerah. Hasil penelitiannya menunjukkan hasil yang positif. Dari sebab itu muncul indikasi bahwa ketepatwaktuan dalam pelaporan keuangan dapat dipengaruhi oleh adanya sistem pengendalian internal. Dengan kata lain sistem pengendalian internal dapat mempengaruhi atau memiliki hubungan akan adanya ketepatwaktuan dalam pelaporan keuangan pemerintah daerah.

Rumusan masalah yang diajukan oleh peneliti yaitu apakah kualitas sumber daya manusia, pemanfaatan teknologi informasi, dan sistem pengendalian internal berpengaruh pada keterandalan serta ketepatwaktuan di dalam laporan keuangan Pemkot Salatiga. Selain itu peneliti juga ingin mencoba melihat dalam konteks yang berbeda yaitu apakah masing-masing dari variabel bebas tersebut lebih dominan dalam mempengaruhi keterandalan ataukan ketepatwaktuan.

Penelitian ini bertujuan untuk memberikan bukti apakah keterandalan serta ketepatwaktuan dipengaruhi oleh adanya faktor-faktor kualitas sumber daya manusia, pemanfaatan teknologi informasi, dan sistem pengendalian internal. Selain itu juga untuk mengetahui masing-masing dari variabel bebas apakah lebih dominan dalam mempengaruhi keterandalan ataukan ketepatwaktuan. Diharapkan penelitian ini dapat bermanfaat bagi Pemkot Salatiga dengan memberikan masukan dan bahan evaluasi bagi unit-unit OPD dalam memberikan laporan keuangannya yang nantinya akan dikonsolidasi menjadi sebuah laporan keuangan Pemkot Salatiga. Peneliti juga berharap agar penelitian ini dapat menjadi bahan referensi yang bermanfaat dalam penelitian- penelitian yang sejenis dimasa mendatang.

\section{Metode Penelitian}

Pendekatan penelitian ini adalah pendekatan kuantitatif. Jenis data yang digunakan adalah data primer yang diperoleh dari hasil kuesioner yang telah dibagikan dan diisi oleh para responden OPD se-Kota Salatiga yang kemudian dikembalikan kepada peneliti untuk diolah. Peneliti menggunakan kuesioner sebagai teknik pengumpulan data dengan bentuk pertanyaan secara tertutup (jawaban dibatasi dengan bentuk pilihan yang sudah disediakan). Kuesioner merupakan pengembangan dari penelitian sebelumnya yaitu penelitian yang telah dilakukan oleh Ariesta (2013). Penelitian ini menggunakan responden seluruh pegawai bagian akuntansi/ keuangan OPD di Kota Salatiga..

Penelitian yang dilakukan ini menggunakan tiga variabel independen, yaitu: kualitas sumber daya manusia, pemanfaatan teknologi informasi, dan sistem pengendalian internal dan dua variabel dependen, yaitu: keterandalan dan ketepatwaktuan pelaporan keuangan pemerintah daerah. Data yang peneliti gunakan dalam penelitian ini adalah data primer berupa hasil kuesioner yang telah dibagikan dan diisi oleh para responden. Definisi operasional untuk masingmasing variabel beserta pengukurannya seperti pada tabel 1 .

Penelitian ini menggunakan metode analisis regresi linear berganda dengan program aplikasi SPSS. Korelasi regresi linear berganda digunakan untuk dapat melihat pengaruh variabel-variabel bebas pada kedua unsur nilai pelaporan keuangan yaitu keteradalan dan ketepatwaktuan. Persamaan korelasi regresi linear berganda dari penelitian ini adalah:

$$
\mathrm{Y}_{1}=\alpha+\mathrm{b}_{1} \mathrm{X}_{1}+\mathrm{b}_{2} \mathrm{X}_{2}+\mathrm{b}_{3} \mathrm{X}_{3}+e
$$


$\mathrm{Y} 2=\alpha+\mathrm{b} 1 \mathrm{X} 1+\mathrm{b} 2 \mathrm{X} 2+\mathrm{b} 3 \mathrm{X} 3+e$

Keterangan:

Y1 : Keterandalan

Y2 : Ketepatwaktuan

$\mathrm{X} 1$ : Kualitas sumber daya manusia

$\mathrm{X} 2$ : Pemanfaatan teknologi informasi

$\mathrm{X} 3$ : Sistem pengendalian internal

$\alpha$ : Konstanta

b1, b2, b3: Koefisien regresi

e : Error

\section{Hasil Dan Pembahasan}

Peneliti telah mendapatkan data yang diperoleh melalui pembagian kuesioner kepada pegawai Organisasi Perangkat Daerah bagian keuangan/akuntansi yang tergambar melalui statistik deskriptif. Informasi yang dapat diberikan tergambar melalui tabel 2

Tabel 1 Definisi Operasional dan Pengukuran Variabel

\begin{tabular}{|c|c|c|c|}
\hline No & Variabel & Definisi & Indikator Empiris \\
\hline 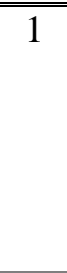 & $\begin{array}{l}\text { Kualitas } \\
\text { Sumber Daya } \\
\text { Manusia }\end{array}$ & $\begin{array}{l}\text { Kualitas sumber daya manusia } \\
\text { adalah kemampuan sumber } \\
\text { daya manusia tersebut dalam } \\
\text { menjalankan tug } \\
\text { 2001). }\end{array}$ & $\begin{array}{l}\text { 1. Minimal berpendidikan } \\
\text { lulusan D3 akuntansi. } \\
\text { 2. Terdapat uraian tugas yang } \\
\text { jelas untuk bagian akuntansi. } \\
\text { 3. Terdapat pedoman tentang } \\
\text { prosedur dan proses akuntansi }\end{array}$ \\
\hline 2 & $\begin{array}{l}\text { Pemanfaatan } \\
\text { Teknologi } \\
\text { Informasi }\end{array}$ & \begin{tabular}{l} 
Pemanfaatan \\
informasi dilihat dari para \\
pengelola keuangan dalam \\
memanfaatkan perangkat \\
komputer untuk proses \\
penyusunan laporan keuangan \\
mulai dari pemrosesan, \\
pengolahan data, dan \\
penyebaran data (Jurnali dan \\
\multicolumn{2}{c}{ Supomo 2002). }
\end{tabular} & $\begin{array}{l}\text { 1. Memiliki komputer yang } \\
\text { cukup untuk digunakan. } \\
\text { 2. Terdapat jaringan internet } \\
\text { dan memanfaatkannya. } \\
\text { 3. Menggunakan komputer dari } \\
\text { awal proses pembuatan } \\
\text { laporan }\end{array}$ \\
\hline 3 & $\begin{array}{l}\text { Sistem } \\
\text { Pengendalian } \\
\text { Internal }\end{array}$ & $\begin{array}{l}\text { Proses yang intregal pada } \\
\text { tindakan dan kegiatan yang } \\
\text { dilakukan secara terus menerus } \\
\text { oleh pimpinan dan seluruh } \\
\text { pegawai untuk memberikan } \\
\text { keyakinan memadai atas } \\
\text { tercapainya tujuan organisasi } \\
\text { melalui kegiatan yang efektif } \\
\text { dan efisien, keandalan } \\
\text { pelaporan keuangan, } \\
\text { pengamanan aset negara, dan } \\
\text { ketaatan terhadap peraturan } \\
\text { perundang-undangan } \\
\text { (Peraturan Pemerintah Nomor } \\
60 \text { Tahun } 2008 \text { Pasal } 1 \text { Ayat } \\
\text { 1). }\end{array}$ & $\begin{array}{l}\text { 1. Selalu melakukan otorisasi } \\
\text { terhadap pihak yang } \\
\text { berwajib jika terdapat } \\
\text { transaksi. } \\
\text { 2. Mencatat setiap adatransaksi. } \\
\text { 3. Terdapat pemisahan tugas } \\
\text { pada bagian akuntansi. }\end{array}$ \\
\hline
\end{tabular}


4 Keterandalan Informasi yang disajikan bebas Pelaporan Keuangan Pemerintah Daerah dari bias dan kesalahan yang signifikan, menyatakan setiap fakta dengan jujur dan dapat dibuktikan kebenarannya (Renyowijoyo 2010).

5 Ketepatwakt uan

Pelaporan

Keuangan

Pemerintah

Daerah

1.Penyajian dengan sebenarbenarnya.

2. Menyajikan semua laporan yang diperlukan.

3. Informasi yang disajikan dapat diuji.

4. Informasi disajikan secara umum

1.Informasi tersedia ketika dibutuhkan.

2.Laporan periode tertentu disediakan secara sistematis dan teratur.

Tabel 2 Statistik Deskriptif

\begin{tabular}{lrrrr}
\hline & Minimal & Maksimal & Rata-Rata & \multicolumn{2}{c}{$\begin{array}{l}\text { Standar } \\
\text { Deviasi }\end{array}$} \\
\hline Sumber Daya Manusia (SDM) & 3,00 & 5,00 & 4,02 & 0,51 \\
Pemanfaatan Teknologi Informasi (PTI) & 3,50 & 5,00 & 4,26 & 0,42 \\
Sistem Pengendalian Internal (SPI) & 3,67 & 5,00 & 4,32 & 0,44 \\
Keterandalan (KTR) & 3,00 & 5,00 & 4,32 & 0,47 \\
Ketepatwaktuan (KPT) & 3,10 & 5,00 & 4,22 & 0,41 \\
\hline
\end{tabular}

Sumber: Lampiran Output Statistik Deskriptif SPSS

Berdasarkan analisis atas kuesioner dapat terlihat karakteristik pegawai pengelola keuangan melalui demografi pengelola keuangan. Demografi tersebut secara umum meliputi jenis kelamin, usia, dan pendidikan terakhir beserta dengan jurusan pendidikannya.

Berdasarkan kuesioner yang dapat diolah yang berjumlah 117 buah, diperoleh karakteristik pegawai bagian keuangan/akuntansi didominasi oleh perempuan sebesar 63,28 persen sedangkan yang berjenis kelamin lakilaki sebanyak 36,75 persen. Dalam hal ketelitian dan kejelian pada bagian keuangan biasanya perempuan lebih teliti dan jeli dari pada laki-laki, sehingga kesalahan dapat diminimalisasi. Pemkot Salatiga sudah didominasi oleh pegawai perempuan pada bagian keuangan/akuntansi.

Karakteristik demografi bagian keuangan/akuntansi berdasarkan usia menunjukkan bahwa pegawai bagian keuangan/akuntansi didominasi oleh pegawai usia 30-39 tahun dengan prosentase sebanyak 47,01 persen, disusul dengan pegawai usia 40- 49 tahun dengan prosentase 29,06 persen. Untuk pegawai dengan rentang usia terbanyak ke tiga yaitu 50-59 tahun memiliki prosentase 17,09 persen, dan yang terakhir rentang usia 20-29 tahun dengan prosentase 6,84 persen. Selain itu diperoleh juga karakteristik demografi masa kerja pada pegawai bagian keuangan/akuntansi didominasi oleh pegawai dengan masa kerja diatas sepuluh tahun dengan prosentase 45,30 
persen, masa kerja antara 5-10 tahun sebanyak 44,44 persen, dan masa kerja dibawah lima tahun sebanyak 10,26 persen. Pegawai dengan masa kerja lebih dari lima tahun biasanya lebih mengerti bagaimana pekerjaan di bagian akuntansi atau keuangan di OPD Kota Salatiga, karena pengalaman yang cukup yang membuat pegawai bagian akuntansi/keuangan menjadi terlatih dengan sendirinya ketika menghadapi pekerjaan di bagian akuntansi/keuangan.

Pegawai bagian akuntansi/ keuangan pada OPD kota Salatiga yang memiliki pendidikan terakhir S1 jurusan akuntansi berjumlah 34,29 persen, dan D3 jurusan akuntansi berjumlah 11,43 persen. Sisanya memiliki pendidikan terakhir dibawah D3 sebanyak 13,33 persen, dan paling banyak adalah memiliki pendidikan terakhir S1 namun bukan berasal dari akuntansi yaitu sebanyak 40,95 persen. Dari paparan prosentase tersebut menunjukkan bahwa latar belakang pendidikan untuk pegawai bagian akuntansi/keuangan belum optimal. Namun latar belakang pendidikan non akuntansi tidak menjadi hambatan bagi pegawai OPD bagian akuntansi/keuangan untuk dapat bekerja di bagian akuntansi/keuangan. Hal ini berhubungan dengan masa kerja yang telah dialami yang mayoritas sudah bekerja di bagian akuntansi/keuangan lebih dari lima tahun.

Uji validitas menggunakan korelasi bivariate menunjukkan bahwa kuesioner yang peneliti pakai sudah valid, artinya kuesioner dapat mengungkapkan sesuatu yang hendak diukur melalui kuesioner yang peneliti pakai. Untuk mengetahui valid tidaknya hasil pengujian yaitu, jika $\mathrm{r}$ hitung $\geq \mathrm{r}$ tabel maka kuesioner dikatakan valid. Hasil uji validitas dapat dilihat pada lampiran tabel 5 uji validitas. Uji reliabilitas menggunakan nilai Chonbach's Alpha, dengan cara membandingkan antara nilai alpha dengan $\mathrm{r}$ tabel. Jika nilai alpha lebih besar dibandingkan $r$ tabel maka kuesioner memenuhi nilai reliabel. Hasil yang diperoleh dari uji reliabilitas yaitu bahwa nilai alpha $0,675>\mathrm{r}$ tabel 0,1801, sehingga disimpulkan bahwa kuesioner memenuhi nilai reliabel

Uji normalitas yang peneliti pakai adalah dengan menggunakan P-Plots. Uji normalitas antara variabel bebas kualitas sumber daya manusia, pemanfaatan teknologi informasi, dan sistem pengendalian internal terhadap keterandalan menunjukkan bahwa data terdistribusi normal yaitu dengan tanda penyebaran data mengikuti garis diagonal. Begitu juga uji normalitas ketiga variabel bebas tersebut terhadap ketepatwaktuan. Kemudian untuk uji heteroskedastisitas yang peneliti pakai adalah dengan menggunakan uji glejser. Hasil menunjukkan antara variabel kualitas sumber daya manusia, pemanfaatan teknologi informasi, dan sistem pengendalian internal terhadap keterandalan dan ketepatwaktuan menunjukkan nilai signifikansi $>\alpha=$ 0,05 . Hasil tersebut menunjukkan tidak adanya gejala heteroskedastisitas pada model regresi. Untuk pengujian multikolinearitas peneliti melihat nilai tolerance dan VIF. Hasil menunjukkan bahwa nilai tolerance pada model regresi $>0,10$, dan nilai VIF < dari 10. Dari hasil tersebut menunjukkan bahwa tidak terdapat multikolinearitas pada model regresi yang peneliti lakukan. Dari hasil tersebut memberikan hasil bahwa data yang peneliti dapatkan sudah lolos uji asumsi klasik dan layak untuk dilakukan pengujian regresi berikutnya.

\section{Pengujian Regresi Variabel Dependen Keterandalan}

Uji $F$ memiliki $F$ statistik 44,489 dengan probabilitas 0,000 sehingga disimpulkan bahwa secara bersama-sama kualitas sumber daya manusia, pemanfaatan teknologi informasi, dan sistem pengendalian internal berpengaruh signifikan terhadap variabel keterandalan. Adjusted $R$ Square menunjukkan $0,529 \quad(52,9 \%)$. Hal ini menunjukkan bahwa pengaruh dari ketiga variabel bebas yaitu kualitas 
sumber daya manusia, pemanfaatan teknologi informasi, dan sistem pengendalian internal terhadap variabel keterandalan yaitu sebesar 52,9\%, sedangkan selebihnya, sebesar 47,1 persen dipengaruhi oleh variabel lain.

Tabel 3 Hasil Pengujian Regresi Berganda dengan Variabel Dependen Keterandalan

\begin{tabular}{lrccr}
\hline Variabel & Coefficient & $\mathbf{t}$ & Sig. & Keterangan \\
\hline (Constant) & 0,375 & 1,085 & 0,280 & \\
Kualitas SDM & 0,110 & 1,606 & 0,111 & H1 ditolak \\
Pemanfaatan TI & 0,361 & 3,984 & 0,000 & H2 diterima \\
SPI & 0,455 & 5,544 & 0,000 & H3 diterima \\
F-Statistic & 44,489 & & & \\
$\mathbf{R}^{2}$ & 0,542 & & & \\
Adjusted R & 0,529 & & &
\end{tabular}

Sumber: Output Lampiran Uji Regresi Terhadap Keterandalan(SPSS)

\section{Pengaruh Kualitas Sumber Daya Manusia Terhadap Keterandalan}

Hasil uji regresi atau uji $\mathrm{t}$ dapat diketahui dengan cara membandingkan antara $\mathrm{t}$ statistik dengan $\mathrm{t}$ tabel. Jika $\mathrm{t}$ statistik lebih besar dari t tabel maka variabel bebas tersebut berpengaruh terhadap variabel terikat. Kemudian jika nilai probabilitas $\mathrm{t}$ statistik lebih kecil dari 0,05 maka disimpulkan variabel bebas tersebut berpengaruh secara signifikan terhadap variabel terikat. Kualitas sumber daya manusia dengan keterandalan menunjukkan $\mathrm{t}$ statistik sebesar $1,060<1,981$ dan nilai signifikansi sebesar $0,111>0,05$ yang berarti bahwa kualitas sumber daya manusia tidak berpengaruh signifikan atas keterandalan laporan keuangan Pemkot Salatiga. Hipotesis pertama ditolak secara statistik.

Pendapat yang dikemukakan oleh Susilo (2002) tidak sepenuhnya berlaku bagi pegawai bagian auntansi/keuangan di lingkungan Pemkot Salatiga. Susilo (2002) mengemukakan bahwa keterandalan dapat dicapai dengan cara memiliki sumber daya manusia yang berkompeten di dalam organisasi diukur dari pendidikan, keterlatihan, dan pengalaman yang dimilikinya. Sumber daya manusia pada bagian akuntansi/ keuangan berkompeten meskipun sebagian besar tidak berlatar belakang akuntansi. Para pegawai relatif terlatih dikarenakan cukup berpengalaman bekerja pada bagian ini. Hal ini dibuktikan dengan hasil kuesioner yang menunjukkan bahwa lebih banyak pegawai yang lulusan sarjana non akuntansi, namun telah bekerja dengan masa jabatan lebih dari sepuluh tahun. Hal ini mengindikasikan bahwa jurusan pendidikan terakhir bukanlah suatu hambatan untuk dapat bekerja menjadi pegawai bagian auntansi/keuangan di Pemkot Salatiga, dan diharapkan keterandalan masih dapat dicapai dengan pegawai berlatar belakang pendidikan non auntansi.

\section{Pengaruh Pemanfaatan Teknologi Informasi Terhadap Keterandalan}

Pengujian antara pemanfaatan teknologi informasi dengan keterandalan menunjukkan nilai $\mathrm{t}$ statistik sebesar 3,984 lebih besar dari t tabel yaitu 1,981. Hal tersebut menunjukkan bahwa terdapat pengaruh antara pemanfaatan teknologi informasi dengan keterandalan. Kemudian nilai probabilitas $\mathrm{t}$ statistik dari kedua variabel tersebut yaitu sebesar 
$0,000<0,05$ sehingga dapat disimpulkan terdapat pengaruh yang positif signifikan antara pemanfaatan teknologi dengan keterandalan, sehingga hipotesis kedua diterima secara stastistik.

Hasil penelitian yang diperoleh sejalan seperti yang tertulis dalam Peraturan Pemerintah Nomor 56 Tahun 2005 yang kemudian diperbaharui dalam Peraturan Pemerintah Nomor 65 Tahun 2010 perihal Sistem Informasi Keuangan Daerah, bahwa pemerintah berkewajiban untuk menggunakan adanya teknologi untuk mengelola keuangan daerah dan menyalurkan informasi tersebut kepada publik. Pemkot Salatiga telah melaksanakan Peraturan Pemerintah tersebut dengan cara telah memanfaatkan teknologi dalam penyusunan laporan keuangannya. Pemkot Salatiga khususnya para pegawai bagian akuntansi/keuangan ternyata mampu menggunakan perangkat teknologi sehingga tercipta adanya keterandalan dalam penyusunan laporan keuangan. Semakin banyak intensitas dalam menggunakan teknologi informasi dan meninggalkan metode konvensional, maka akan semakin tercipta laporan keuangan yang andal di lingkup Pemerintahan Kota Salatiga. Hasil penelitian ini sejalan dengan penelitian yang telah dilakukan oleh Megayanti, Adiputra dan Sinarwati (2015), Sari dan Witono (2014), Darwanis dan Mahyani (2009).

\section{Pengaruh Sistem Pengendalian Internal Terhadap Keterandalan}

Pengujian hipotesis antara sistem pengendalian internal terhadap keterandalan menunjukkan hasil $t$ statistik sebesar 5,544 >1,981 dengan probabilitas $\mathrm{t}$ statistik sebesar $0,000<$ 0,05 . Hasil pengujian tersebut menunjukkan bahwa terdapat pengaruh yang positif signifikan antara sistem pengendalian internal dengan
keterandalan

pemerintah daerah Dengan demikian hipotesis ketiga diterima secara statistik.

Hasil penelitian yang didapatkan ternyata menunjukkan bahwa sistem pengendalian internal membantu terciptanya laporan keuangan yang andal. Konsisten dengan Peraturan Pemerintah Nomor 60 Tahun 2008 tentang Sistem Pengendalian Internal bahwa sistem pengendalian diperlukan untuk memberikan keyakinan kepada pemakai laporan keuangan perihal mengenai keandalan, pengamanan aset, dan ketaatan terhadap peraturan-peraturan. Pemkot Salatiga telah menerapakan sitem pengendalian pada bagian auntansi/keuangan untuk menjaga agar komponen-komponen dapat berjalan sebagaimana mestinya sehingga dapat menghindari kesalahan-kesalahan yang disengaja maupun yang dilakukan tanpa sengaja untuk mencapai nilai keterandalan. Dari hasil yang diperoleh dapat disimpulkan bahwa keterandalan laporan keuangan tidak dapat dipisahkan oleh suatu sistem pengendalian internal di dalam sebuah organisasi pemerintahan. Semakin baik sistem pengendalian yang diterapkan di lingkungan organisasi Pemkot Salatiga, maka akan semakin tercipta nilai keterandalan laporan keuangan Pemkot Salatiga. Hasil penelitian ini sejalan dengan hasil penelitian Darwanis dan Mahyani (2009), Sari dan Witono (2014), Surastiani dan Handayani (2015), Megayanti, Adiputra dan Sinarwati (2015).

\section{Pengujian Regresi Variabel Dependen Ketepatwaktuan}

Pengujian berikut dilakukan untuk membuktikan hipotesi 4-6. Hasil pengujian dengan menggunakan regresi berganda tampak pada table 4 
Tabel 4 Hasil Pengujian Regresi dengan Variabel Dependen Ketepatwaktuan

\begin{tabular}{lcccc}
\hline Variabel Independen & Coefficient & t & Sig. & Keterangan \\
\hline (Constan) & 0,667 & 2,332 & 0,021 & \\
Kualitas SDM & 0,156 & 2,690 & 0,008 & H4 diterima \\
Pemanfaatan TI & 0,339 & 4,455 & 0,000 & H5 diterima \\
SPI & 0,340 & 4,936 & 0,000 & H6 diterima \\
F-Statistic & $: 50,087$ & & 0,000 & \\
$\mathrm{R}^{2}$ & 0,571 & & & \\
Adjusted R $^{2}$ & 0,559 & & & \\
\hline
\end{tabular}

Sumber: Lampiran Output Uji Regresi Terhadap Ketepatwaktuan

Dari model regresi yang diperoleh dapat disimpulkan jika kualitas sumber daya manusia, pemanfaatan teknologi informasi, dan sistem pengendalian internal berpengaruh positif terhadap ketepatwaktuan. Apabila ketiga variabel bebas tersebut mengalami kemajuan peningkatan yang lebih baik maka nilai ketepatwaktuan akan menjadi semakin baik pula.

Nilai F statistik pada pengujian variabel bebas terhadap variabel ketepatwaktuan yaitu sebesar 50,087 dan lebih besar dari $F$ tabel yaitu sebesar 2,45 , sehingga secara bersama-sama ketiga variabel bebas mempengaruhi variabel terikat ketepatwaktuan. Kemudian nilai probabilitas dari uji $\mathrm{F}$ yaitu sebesar 0,000 dan lebih kecil dari 0,05 sehingga memiliki pengaruh yang signifikan. Disimpulkan bahwa secara simultan kualitas sumber daya manusia, pemanfaatan tekologi informasi, dan sistem pengendalian internal berpengaruh secara signifikan pada variabel ketepatwaktuan. Adjusted $R$ Square digunakan untuk mengetahui pengaruh dari ketiga variabel bebas kualitas sumber daya manusia, pemanfaatan teknologi informasi, dan sistem pengendalian internal terhadap ketepatwaktuan. Hasil menunjukkan $0,559 \quad(55,9 \%)$ yang berarti bahwa kualitas sumber daya manusia, pemanfaatan teknologi informasi, dan sistem pengendalian internal mempengaruhi variabel ketepatwaktuan sebesar 55,9 persen sedangkan selebihnya sebesar 44,1 persen dipengaruhi oleh variabel lain.

\section{Pengaruh Kualitas Sumber Daya Manusia Terhadap Ketepatwaktuan}

Pengaruh antara kualitas sumber daya manusia dengan ketepatwaktuan dapat dilihat dengan dua cara. Yaitu yang pertama dengan membandingkan antara $t$ statistik dengan $t$ tabel. Jika t statistik lebih besar dari t tabel maka variabel bebas tersebut berpengaruh terhadap variabel terikat. Yang kedua dengan cara melihat nilai probabilitas, jika probabilitas $\mathrm{t}$ statistik lebih kecil dari 0,05 maka variabel bebas berpengaruh secara signifikan terhadap variabel terikatnya. Hasil uji regresi menunjukkan t statistik sebesar 2,690 > t tabel 1,981 dengan probabilitas $\mathrm{t}$ statistik $0,008<$ 0,05 sehingga disimpulkan bahwa terdapat pengaruh yang positif signifikan antara kualitas sumber daya manusia dengan ketepatwaktuan, sehingga hipotesis keempat diterima secara statistik.

Hasil tersebut konsisten dengan penelitian yang dikemukakan oleh Winidyaningrum dan Rahmawati (2010) bahwa ketepatwaktuan atas laporan keuangan dapat dicapai dengan adanya bantuan dari sumber daya manusia sehingga penyajian laporan keuangan dapat tepat waktu. Sumber daya manusia yang dimiliki oleh Pemerintah Kota 
Salatiga dapat membantu mewujudkan terbentunya laporan keuangan pemerintah daerah secara tepat waktu, sehingga ketika dibutuhkan laporan keuangan tidak akan terlambat penyajiannya. Dari hasil pengujian yang didapatkan ini, diketahui bahwa penting untuk merekrut sumber daya manusia yang berkompeten di bidang akuntansi/keuangan di lingkup Pemerintahan Kota Salatiga. Hasil pengaruh yang positif signifikan menyimpulkan bahwa semakin baik kualitas sumber daya manusia yang dimiliki oleh Pemkot Salatiga maka akan semakin mendukung terciptanya laporan keuangan pemerintah daerah yang tepat waktu.

\section{Pengaruh Pemanfaatan Teknologi Informasi Terhadap Ketepatwaktuan}

$\begin{array}{rrr}\text { Pengujian antara } & \text { pemanfaatan } \\ \text { teknologi informasi } & \text { terhadap }\end{array}$ ketepatwaktuan memperoleh hasil bahwa t statistik sebesar 4,455 > 1,981, dengan probabilitas t statistik sebesar $0,000<$ 0,05 . Hasil tersebit menunjukkan bahwa pemanfaatan teknologi informasi memiliki pengaruh yang positif signifikan atas ketepatwaktuan pelaporan keuangan. Dengan demikian hipotesis kelima diterima secara statistik.

Dimanfaatkannya teknologi informasi membuat laporan keuangan pemerintah menjadi tepat waktu. Hal ini sejalan dengan pernyataan Sari dan Witono (2014) yang menyatakan bahwa pemanfaatan teknologi informasi memiliki peran pada terselesaikannya laporan keuangan pemerintah secara tepat waktu sehingga laporan keuangan tidak kehilangan nilainya. Pemkot Salatiga telah menggunakan perangkat komputer dalam hal pemprosesan, menyimpanan data keuangan, dan penyebaran data keuangan melalui jaringan internet sehingga dapat terlaksana tanpa memakan waktu yang lama. Terselesaikannya laporan keuangan yang tanpa memakan waktu lama ini membuat laporan keuangan tidak kehilangan nilainya yaitu ketepat- waktuan, sehingga ketika dibutuhkan untuk suatu hal laporan keuangan Pemkot Salatiga sudah tersedia tanpa adanya keterlambatan. Hasil penelitian ini sejalan dengan penelitian Sari dan Witono (2014).

\section{Pengaruh Sistem Pengendalian Internal Terhadap Ketepatwaktuan}

$\begin{array}{lcr}\quad \text { Pengujian } & \text { antara } & \text { sistem } \\ \text { pengendalian } & \text { internal } & \text { dengan } \\ \text { ketepatwaktuan } & \text { menunjukkan } & \text { hasil }\end{array}$
bahwa $\mathrm{t}$ statistik 4,936>t tabel 1,981 dengan nilai probabilitas $\mathrm{t}$ statistik sebesar $0,000<0,05$. Hasil pengujian ini menunjukkan bahwa terdapat pengaruh yang positif signifikan antara sistem pengendalian internal terhadap ketepatwaktuan pelaporan keuangan pemerintah daerah. Dengan demikian hipotesis keenam diterima secara statistik.

Hasil penelitian yang didapatkan konsisten dengan penelitian yang dilakukan oleh Mirnayanti (2013) yang menyatakan bahwa asas ketertiban dalam laporan keuangan dapat ditunjukkan dengan adanya laporan keuangan yang tepat waktu yang tercipta karena adanya sistem pengendalian internal yang layak. Pemkot Salatiga mampu mengintegrasikan sistem pengendalian yang baik untuk menjaga unsur-unsur yang ada didalam organisasi khususnya yang terdapat di bagian akuntansi/keuangan supaya dapat beroperasi dengan baik. Jika unsur-unsur yang terdapat pada bagian akuntansi /keuangan dapat berjalan dengan baik maka diharapkan bahwa dapat mencegah terjadinya kekeliruan dan menghasilkan laporan keuangan yang tepat waktu. Disimpulkan bahwa semakin baik sistem pengendalian internal maka akan menyebabkan semakin terciptanya laporan keuangan pemerintah yang tepat waktu.

\section{Simpulan}

Kualitas sumber daya manusia, pemanfaatan teknologi informasi, dan sistem pengendalian internal lebih 
dominan berpengaruh atas ketepatwaktuan laporan keuangan. Dalam mewujudkan tujuan atas laporan keuangan yaitu supaya dapat dipakai oleh para pemangku kepentingan, keterandalan dan ketepatwaktuan harus berjalan seimbang atau beriringan. Di lingkungan pemerintah Kota Salatiga keterandalan dan ketepatwaktuan dalam membuat laporan keuangan daerah hanya memiliki selisih sebesar 3 (tiga) persen yang tidak terlalu besar perbedaannya. Artinya bahwa Pemkot Salatiga mampu untuk menyelaraskan antara sumber daya manusia, teknologi informasi, dan sistem pengendalian internal untuk membagi fokusnya kepada dua unsur utama yaitu membuat laporan keuangan yang andal sekaligus tepat waktu.

Kualitas sumber daya manusia tidak berpengaruh positif atas terciptanya keterandalan laporan keuangan pemerintah daerah. Karena, latar belakang pendidikan belum tentu dapat menghalangi pegawai berlatar belakang pendidikan non akuntansi untuk bekerja di bagian akuntansi/keuangan. Pengalaman yang cukup dapat membuat pegawai bisa untuk mengelola bagian akuntansi/keuangan. Kualitas sumber daya manusia berpengaruh positif signifikan atas terciptanya ketepatwaktuan laporan keuangan pemerintah daerah. Jika kualitas sumber daya manusia yang dimiliki oleh pemerintah Kota Salatiga semakin baik maka akan semakin meningkatkan terciptanya laporan keuangan pemerintah yang memenuhi kriteria tepat waktu.

Variabel pemanfaatan teknologi informasi berpengaruh positif signifikan terhadap keterandalan. Hal ini menunjukkan bahwa semakin banyak memanfaatkan teknologi informasi dan meninggalkan cara konvensional maka dapat membantu semakin terciptanya laporan keuangan pemerintah yang semakin andal. Pemanfaatan teknologi informasi juga berpengaruh positif signifikan terhadap ketepatwaktuan laporan keuangan. Jika intensitas pemanfaatan teknologi informasi semakin meningkat dan mengurangi cara yang konvensional maka akan semakin meningkatkan nilai informasi laporan keuangan berupa ketepatwaktuan.

Sistem pengendalian internal berpengaruh positif signifikan terhadap keterandalan laporan keuangan pemerintah Kota Salatiga. Semakin baik sistem pengendalian internal yang ada di dalam organisasi pemerintahan maka akan semakin mendukung terciptanya laporan keuangan yang andal. Selain itu sistem pengendalian internal juga berpengaruh positif signifikan terhadap ketepatwatuan laporan keuangan pemerintah Kota Salatiga. Semakin baik sistem pengendalian internal yang diterapkan dalam organisasi pemerintahan maka akan semakin mendukung tercitanya laporan keuangan yang tepat waktu.

Keterbatasan yang peneliti hadapi ialah bahwa penelitian hanya dilakukan dengan metode pembagian kuesioner sehingga mengurangi objektivitas dan menyebab-kan peneliti tidak dapat menangkap peristiwa secara lebih nyata yang terdapat di lingkungan OPD Kota Salatiga. Selain itu kuesioner terdapat kemungkinan pengisian berdasar persepsi subyektif responden untuk memilih jawaban yang cenderung baik. Disarankan penelitian sejenis yang akan datang dapat melakukan pengumpulan data dengan lebih memperhatikan cara pengumpulan data sehingga bisa menangkap peristiwa-peristiwa yang lebih nyata yang terdapat di lokasi penelitian. Disisi lain kuesioner dibagikan kepada para responden dengan meninggalkannya dan beberapa hari kemudian baru diambil oleh peneliti. Hal tersebut membuat peneliti tidak dapat memonitor secara langusng bagaimana para responden mengisi kuesioner tersebut. Disarankan supaya penelitian berikutnya lebih memperhatikan bagaimana strategi pengumpulan data dengan menggunakan kuesioner supaya pengisian dapat dipantau dengan baik.

Variabel bebas yang digunakan dalam penelitian ini hanya mampu 
menjelaskan 52,9 persen atas keterandalan, dan 55,9 persen atas ketepatwaktuan. Disarankan agar penelitian sejenis di masa mendatang dapat menganalisa faktor atau variabel lain yang turut serta dalam mempengaruhi keterandalan dan ketepatwaktuan laporan keuangan pemerintah daerah. Disarankan supaya lingkungan Pemkot Salatiga khususnya di OPD bagian akuntansi/keuangan untuk terus dapat meningkatkan kemampuan dalam mengoperasikan teknologi informasi beserta dengan jaringan internet supaya pekerjaan dapat menjadi lebih praktis untuk dikerjakan. Selain itu juga dapat membantu untuk mengurangi kesalahan dalam perhitungan dan dapat menghemat waktu pekerjaan. Disarankan juga supaya Pemkot Salatiga untuk tetap dapat merekrut pegawai yang memiliki kompetensi yang ahli di bagian akuntansi/keuangan dengan diimbangi oleh peningkatan sistem pengendalian internal yang baik. Hal ini bertujuan agar predikat opini Wajar Tanpa Pengecualian dari BPK dapat terus disandang oleh Pemkot Salatiga supaya akuntabilitas publik dapat terus terlaksana dengan baik pula.

\section{Daftar Pustaka}

Arfianti, Dita. 2011. "Analisis FaktorFaktor yang Mempengaruhi Nilai informasi Pelaporan Keuangan Pemerintah Daerah." Skripsi.

Ariesta, Fadila. 2013. "Pengaruh Kapasitas Sumber Daya Manusia, Pemanfaatan Teknologi Informasi, dan Pengendalian Intern Akuntansi terhadap Nilai Informasi Pelaporan Keuangan Pemerintah Daerah (Studi pada Satuan Kerja Perangkat Daerah di Kabupaten Pasaman Barat)." Jurnal Akuntansi 1.

BPK RI. 2017. Laporan Hasil Pemeriksaan BPK atas Laporan Keuangan Pemerintah Daerah Kota Salatiga Tahun 2016.
Badan Pemeriksa Keuangan

Republik Indonesia.

- 2017. Laporan Hasil Pemeriksaan $B P K$ atas Laporan Keuangan Pemerintah Daerah Kota Salatiga Tahun 2016, Laporan Hasil Pemeriksaan atas Laporan Keuangan. Semarang: Badan Pemeriksa Keuangan.

Clatworthy, Mark A, dan Michael J. Peel. 2010. "Does Corporate Governance Influence the Timeliness of Fiancial Reporting ? Evidence from UK Private Companies." Accounting and Management Control Departement Research Seminar 1.

Darwanis, dan Desi Dwi Mahyani. 2009. "Pengaruh Kapasitas Sumber Daya Manusia, Pemanfaatan Tehnologi Informasi, dan Pengendalian Intern Akuntansi Terhadap Keterandalan Pelaporan Keuangan Pemerintah Daerah." Jurnal Telaah dan Riset Akuntansi.

Halim, Abdul. 2002. Akuntansi dan Pengendalian Keuangan Daerah. Yogyakarta: AMP YKPN.

Hamzah. 2009. "Pengaruh Ekspektasi Kinerja, Ekspektasi Usaha, Faktor Sosial, Kesesuaian Tugas dan Kondisi yang Memfasilitasi Pemakai terhadap Minat Pemanfaatan Sistem Informasi (Studi Empiris pada pemerintahan Kabupaten di Pulau Madura)." Jurnal Nasional Sistem Teknologi Informasi.

Haryanto. 2013. Pengelolaan dan Akuntansi Keuangan Daerah. Semarang. Undip Press

Hidayat, Anwar. 2017. Penjelasan Teknik Sampling dalam Penelitian. 2 Juni. Diakses Juli 9, 2017. https://www.statistikian.com/201 7/06/teknik-sampling-dalampenelitian.html.

-. 2016. Penjelasan Tentang Analisis Multivariat dan Jenisnya. 24 November. Diakses Juli 9, 2017. 
https://www.statistikian.com/201

6/11/analisis-multivariat.html.

Indriasari, D, dan E Nahartyo. 2008.

"Pengaruh Kapasitas Sumber

Daya Manusia, Pemanfaatan

Teknologi Informasi, dan

Pengendalian Intern Akuntansi

terhadap Nilai Informasi

Pelaporan Keuangan

Pemerintah Daerah (Studi pada

Pemerintah Kota Palembang dan Kabupaten Ogan Ilir)." Simposium Nasional Akuntansi, $X I$.

Jurnali, Teddy, dan Bambang Supomo. 2002. "Pengaruh faktor-Faktor Kesesuaian Tugas Teknologi dan Pemanfaatan Teknologi Informasi terhadap Kinerja Akuntan Publik." Jurnal Riset Akuntansi Idonesia 214-228.

Karmila, Amries Tanjung, dan Edfan Darlis. 2013. "Pengaruh Kapasitas Sumber Daya Manusia, Pemanfaatan Teknologi Informasi, dan Pengendalian Intern Akuntansi Terhadap Keterandalan Pelaporan Keuangan Pemerintah Daerah (Studi Pada Pemerintah Provinsi Riau)." Jurnal Sorot 9.

Mamduh, M. Hanafi, dan Abdul Halim. 2003. Analisis Laporan Keuangan. Yogyakarta: UPP AMP YKPN.

Megayanti, Ayu Priska, I Made Adiputra, dan Ni Kadek Sinarwati. 2015. "Faktor-Faktor yang Memengaruhi Keterandalan Nilai Informasi Pelaporan Keuangan Pemerintah Daerah (Studi Kasus Pada Satuan Kerja Perangkat Daerah Kabupaten Jembrana)." E-Jurnal $A k$ Universitas Pendidikan Ganesha.

Mirnayanti. 2013. "Pengaruh Kapasitas Sumber Daya Manusia, Pemanfaatan Teknologi Informasi, dan Pengendalian Intern Terhadap Nilai Informasi

\section{Pelaporan \\ Pemerintah Daerah." Skripsi. \\ Keuangan}

Mulyadi. 2001. Sistem Akuntansi. Jakarta: Salemba Empat.

Notoadmodjo, Soekidjo. 2003. Pengembangan Sumber Daya Manusia. Jakarta: PT. Rineka Cipta.

Pemerintah Republik Indonesia. 2006. Peraturan Menteri Dalam Negeri Nomor 13 Tahun 2006 Tentang Pedoman Pengelolaan Keuangan Daerah.

-. 2008. Peraturan Pemerintah Nomor 60 Tahun 2008 tentang Sistem Pengendalian Intern. Jakarta: Sekretariat Negara.

-. 2010. Peraturan Pemerintah Nomor 65 Tahun 2010 tentang Sistem Informasi Keuangan Daerah. Jakarta: Sekretariat Negara.

- 2010. Peraturan Pemerintah Nomor 71 Tahun 2010 tentang Standar Akuntansi Pemerintahan. Jakarta: Sekretariat Negara. Renyowijoyo, Muindro. 2010. Akuntansi Sektor Publik Organisasi Non Laba. Vol. 2.Jakarta: Mitra Wacana Media.

Riadi, Edi. 2016. Statistika Penelitian (Analisis Manual dan IBM SPSS). Yogyakarta: Andi.

Sari, Shinta Permata, dan Banu Witono. 2014. "Keterandalan dan Ketepatwaktuan Pelaporan Keuangan Daerah Ditinjau dari Sumber Daya Manusia, Pengendalian Internal dan Pemanfaatan Teknologi Informasi." Seminar Nasional dan Call for Paper: Research Methods and Organizational Studies 418-425.

Setiawan. 2017. Belasan Tahun Menunggu, Pemkot Salatiga Akhirnya Raih Predikat Wajar Tanpa SPSS 21. Yogyakarta: Andi.

Surastiani, Dyah Puri, dan Bestari Dwi Handayani. 2015. "Analisis Faktor-Faktor yang Mempengaruhi Kualitas Informasi Laporan 
Keuangan Pemerintah Daerah." Jurnal Dinamika Akuntansi.

Susilo, Martoyo. 2002. Manajemen

Sumber Daya Manusia. Vol. 8.
Yogyakarta: BPFE.

Suwardjono. 2005. Teori Akuntansi

Perekayasaan Pelaporan

Keuangan. Yogyakarta: BPFE. 